\title{
The Impacts of Flood and Drought on Food Security in Central Java
}

\author{
Endita Prima Ari Pratiwi ${ }^{*}$, Eka Laily Ramadhani, Fatchan Nurrochmad, Djoko Legono \\ Department of Civil and Environmental Engineering, Universitas Gadjah Mada, Yogyakarta, INDONESIA \\ Jalan Grafika No 2 Yogyakarta \\ *Corresponding authors: endita.prima.ari.pratiwi@ugm.ac.id
}

SUBMITTED 26 November 2019 REVISED 5 December 2019 ACCEPTED 2 January 2020

\begin{abstract}
To achieve food security, water must be available at the right place, at the right time, in the right quantity, and be of the right quality. Water-related disasters will negatively affect agricultural areas and crop production, which can threaten food security. Nevertheless, flood and drought strike Central Java, one of the rice production centres in Indonesia, every year, and climate change has been worsening the condition because extreme events occur more frequently. This study reviews the impacts of flood and drought on paddy fields in Central Java from 2014 to 2018. A set of historical documents, including reports on flood and drought, rainfall records, and rice production, were collected from government institutions. Quantitative analysis was conducted using statistics and geographic information system tools. The results showed that the 2014 flood event reflected badly on 94,306 hectares (ha) paddy fields. Four severely affected regencies were Pati (25,460 ha), Demak (13,560 ha), Jepara (13,281 ha), and Kudus (12,203 ha). Meanwhile, drought in 2015 affected 82,324 ha paddy field. The areas severely damaged by drought were Blora (12,335 ha), Cilacap (11,503 ha), Grobogan (10,514 ha), and Pemalang (10,134 ha). Pearson's correlation analysis results indicated that the correlation between annual rainfall and drought impact $(r=-0.865, p=0.058)$ is more significant than that between annual rainfall and drought impact $(r=0.794, p=0.108)$. The stakeholders have adopted some strategies to minimise losses, such as establishing a 1,000 small water reservoirs program, preparing temporary pump irrigation, and providing agricultural insurance. Nevertheless, more efforts are still necessary to fight against food insecurity.
\end{abstract}

KEYWORDS Water-food Security Nexus; Water-related Disaster; Climate Change; Disaster Mapping

(c) The Author(s) 2020. This article is distributed under a Creative Commons Attribution-ShareAlike 4.0 International license.

\section{INTRODUCTION}

One of the sustainable development goals is achieving a "zero hunger" world, in other words, food security for all. The Food and Agriculture Organization (FAO, 1996) defines food security as a situation that exists when all people, at all times, have physical, social, and economic access to sufficient, safe, and nutritious food that meets their dietary needs and food preferences for an active and healthy life. The definition involves four aspects of food security, namely, food availability, food stability, food access, and food utilisation. Water security and food security have a complex interrelation, termed as the water-food security nexus. Food production by far accounts for the largest use of global freshwater supplies. Agriculture is responsible for over $70 \%$ of freshwater consumption in the world. Water must be available at the right place, at the right time, in the right quantity, and be of the right quality to achieve food security.

Water-related disasters create water insecurity and cause negative impacts on agricultural areas and crop production, which can endanger food security. Climate change is placing a stronger pressure on the resource farmers depend on, increasing the risks associated with disasters. The impacts of disasters are greater in developing countries than in developed countries (Lolemtum et al., 2017; Marfai et al., 2008; Pacetti et al., 2017). Disasters have affected more than 1.9 billion people and caused over USD 494 billion in estimated damage in developing countries from 2003 to 2013 (FAO, 2015). The agriculture sector accounts for about $25 \%$ of the total damage and losses caused by climate-related disasters. Furthermore, floods, droughts, and tropical 
storms are among the natural hazards affecting the agriculture sector, demonstrating the severe impact of climate-related disasters. Guo et al. (2019) studied five natural disaster types, including floods, droughts, hail, low-temperature events, and typhoon, in Mainland China and found that drought and flood were the most severe disaster types over the last four decades, accounting for over $50 \%$ of total grain losses. The flood or drought event may evolve into a food crisis (Devereux, 2007) because they trigger not only harvest failures but also a sequence of knock-on shocks to local economies and societies.

Central Java is one of the major rice-producing areas in Indonesia, after West Java and East Java; however, this province suffers from various natural hazards more than other areas in Indonesia (Indonesia Disaster Data Information, 2019; Maarif, 2011; Marfai et al., 2008). Sumastuti and Pradono (2016) investigated the impact of climate change, including the impacts of flood, drought, and crop pests, on paddy fields in Central Java. However, their analysis covers the period of 2010-2014. Following previous research, the current study reviews the impacts of flood and drought on paddy fields in Central Java from 2014 to 2018. Some adaptive strategies to flood and drought mitigation for minimizing the risks are also presented.

\section{METHODS}

\subsection{Study Area}

Central Java is a province in Indonesia, located in the middle part of Java Island $\left(6^{\circ} 40^{\prime} \mathrm{S}-8^{\circ} 30^{\prime} \mathrm{S}\right.$, $108^{\circ} 30^{\prime} \mathrm{E}-111^{\circ} 30^{\prime} \mathrm{E}$, excluding Karimun Jawa Archipelago), with a total area of $32,548 \mathrm{~km}^{2}$. It is administratively divided into 29 regencies and six cities (Figure 1), with a population of more than 34 million in 2018. It is located in a tropical zone with monsoon-type rainfall: wet season (October-March) and dry season (AprilSeptember). The annual rainfall is about 2,000 $\mathrm{mm}$. The average temperature is between $18^{\circ} \mathrm{C}$ and $32^{\circ} \mathrm{C}$, and the relative humidity varies between $73 \%$ and $94 \%$.

\subsection{Data Resources}

Historical data were collected from official documents issued by governmental institutions. Reports by the Ministry of Agriculture, Republic

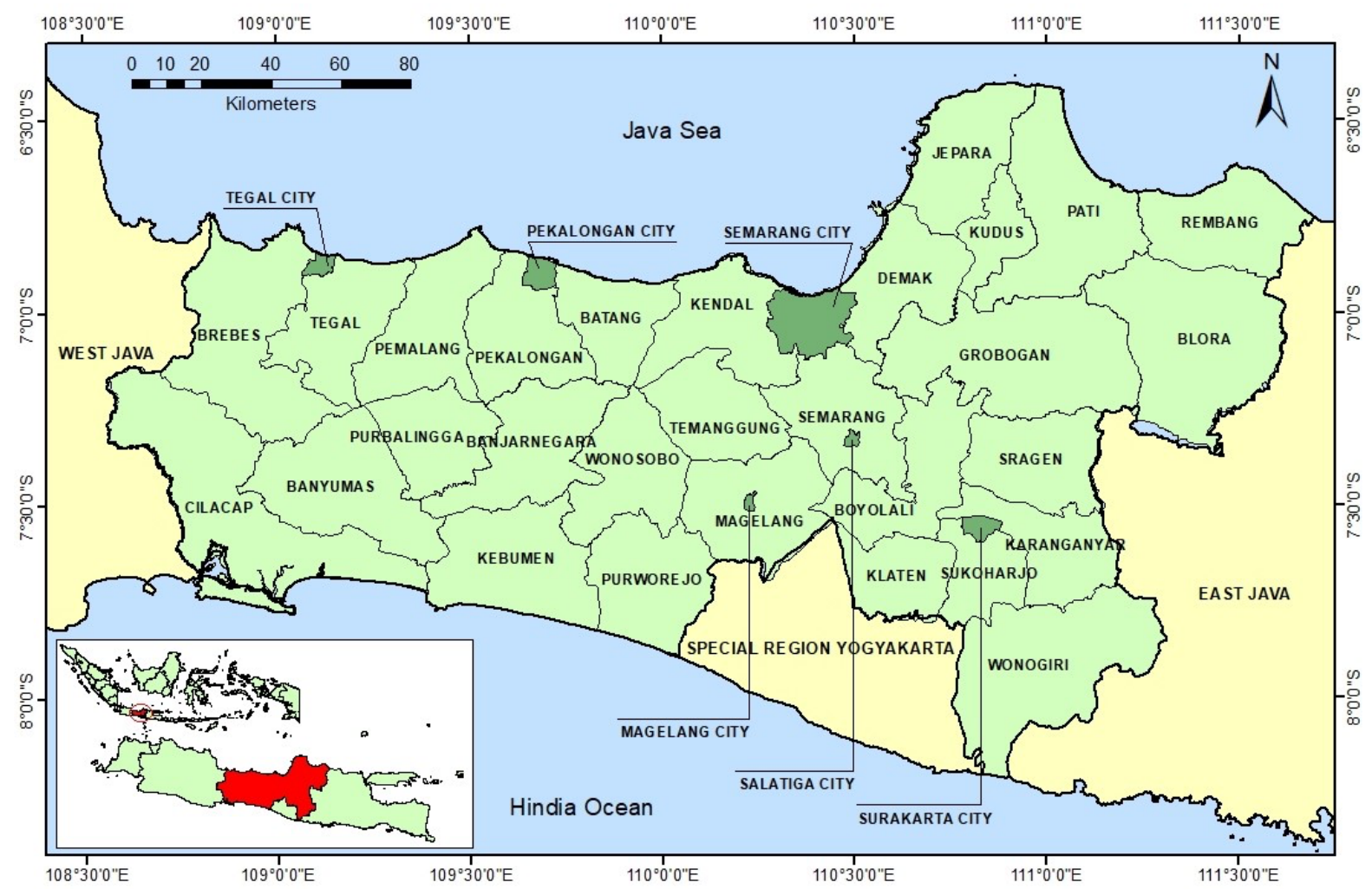

Figure 1. Central Java administrative map 
of Indonesia, (2015, 2018a, 2018b) entitled "Statistics of Agricultural Land" and "Statistics of Climate, Crop Pest and Climate Change Impact," as well as "Statistical Data of Crops in Central Java 2015" published by the Office of Agriculture and Plantation (2016), provide information on monthly rainfall records, rice production, cultivated area, and flood- and drought-affected paddy field areas. This study uses these reported data from 2014 to 2018.

\subsection{Data Analysis}

All data were arranged and analyzed using statistics and geographic information system tools. Pearson's correlation ( $r$ ) analysis was used to determine whether annual rainfall has a linear correlation with flood and drought impact. Pearson's correlation coefficient is calculated using Equation (1).

$$
r=\frac{\sum_{i=1}^{n}\left(x_{i}-\bar{x}\right)\left(y_{i}-\bar{y}\right)}{\sqrt{\sum_{i=1}^{n}\left(x_{i}-\bar{x}\right)^{2}} \sqrt{\sum_{i=1}^{n}\left(y_{i}-\bar{y}\right)^{2}}}
$$

where $r$ is the Pearson's correlation coefficient, $x$ is the annual rainfall, and $y$ is the flood or drought impact.

The $p$-value is used to determine whether the correlation coefficient is statistically significant. If the $p$-value is more than the significance level $(\alpha=0.1)$, then the correlation between variables is significant.

\section{RESULTS AND DISCUSSION}

\subsection{Impacts of Flood and Drought on Paddy Field Areas}

Food security is strictly related to water. Both food and water security are highly vulnerable to continuously changing climatic patterns. The Food and Agriculture Organization (2015) lists five direct impacts of climate-related disasters on agricultural sectors: damage to crops, damage to agricultural infrastructure, damage to suppliers of agricultural sectors, damage to transport and communication, and damage to natural resources supporting agriculture. The current study focuses on the effects of flood and drought on food availability by estimating the crops damaged by the flood and drought events.

Central Java Province has more frequent flood events than the other provinces in Java Island. The most devastating flood in the last five years (2014-2018) occurred in 2014 (Table 1). As much as 60,514 hectares of paddy field areas (3.35\% of the total cultivated area) were affected, and 33,792 hectares suffered from crop failure. The estimated rice production loss in 2014 was 505,197 tons (5.24\% of actual rice production). The most-affected areas were situated in Pati, Demak, Jepara, and Kudus regencies, as displayed in Figure 2. The most flood-prone areas seem to change with time. Sumastuti and Pradono (2016) found that from 2010 to 2014, the most floodprone areas in Central Java were Cilacap and Jepara. Meanwhile, in 2007, the areas most impacted by the flood were Cilacap, Kudus, and Brebes (Marfai et al., 2008). 
Table 1. Paddy field areas in Central Java affected by flood

\begin{tabular}{|c|c|c|c|c|c|c|c|c|c|}
\hline \multirow{3}{*}{ Year } & \multirow{3}{*}{$\begin{array}{c}\begin{array}{c}\text { Total } \\
\text { cultivated } \\
\text { area }\end{array} \\
\text { ha }\end{array}$} & \multirow{3}{*}{$\begin{array}{c}\text { Actual rice } \\
\text { production }\end{array}$} & \multirow{3}{*}{$\begin{array}{c}\begin{array}{c}\text { Land } \\
\text { productivity }\end{array} \\
100 \mathrm{~kg} / \mathrm{ha}\end{array}$} & \multicolumn{6}{|c|}{ Flood impact } \\
\hline & & & & \multicolumn{2}{|c|}{ Affected crop area } & \multicolumn{2}{|c|}{ Crop failure area } & \multicolumn{2}{|c|}{$\begin{array}{c}\text { Estimated } \\
\text { production loss }\end{array}$} \\
\hline & & & & ha & $\%$ & ha & $\%$ & tons & $\%$ \\
\hline (1) & (2) & (3) & (4) & (5) & (6) & (7) & (8) & (9) & (10) \\
\hline 2014 & $1,804,697$ & $9,648,104$ & 53.57 & 60,514 & 3.35 & 33,792 & 1.87 & 505,197 & 5.24 \\
\hline 2015 & $1,864,605$ & $11,301,422$ & 60.25 & 12,325 & 0.66 & 1,526 & 0.08 & 83,452 & 0.74 \\
\hline 2016 & $1,953,593$ & $11,473,161$ & 58.73 & 41,376 & 2.12 & 7,994 & 0.41 & 289,950 & 2.53 \\
\hline 2017 & $2,010,465$ & $11,396,263$ & 56.68 & 29,326 & 1.46 & 6,648 & 0.33 & 203,901 & 1.79 \\
\hline 2018 & $1,954,476$ & $11,401,821$ & 58.34 & 16,919 & 0.87 & 3,523 & 0.18 & 119,259 & 1.05 \\
\hline
\end{tabular}

Notes:

(1), (2), (3), (4) Data sources: Ministry of Agriculture, Republic of Indonesia (2019)

(5), (7) Data sources: Ministry of Agriculture, Republic of Indonesia (2018b, 2015)

(6) $=(5) \div(2) \times 100 \%$

$(8)=(7) \div(2) \times 100 \%$

$(9)=[(5)+(7)] \div(2) \times 100 \%$

$(10)=(9) \div(2) \times 100 \%$

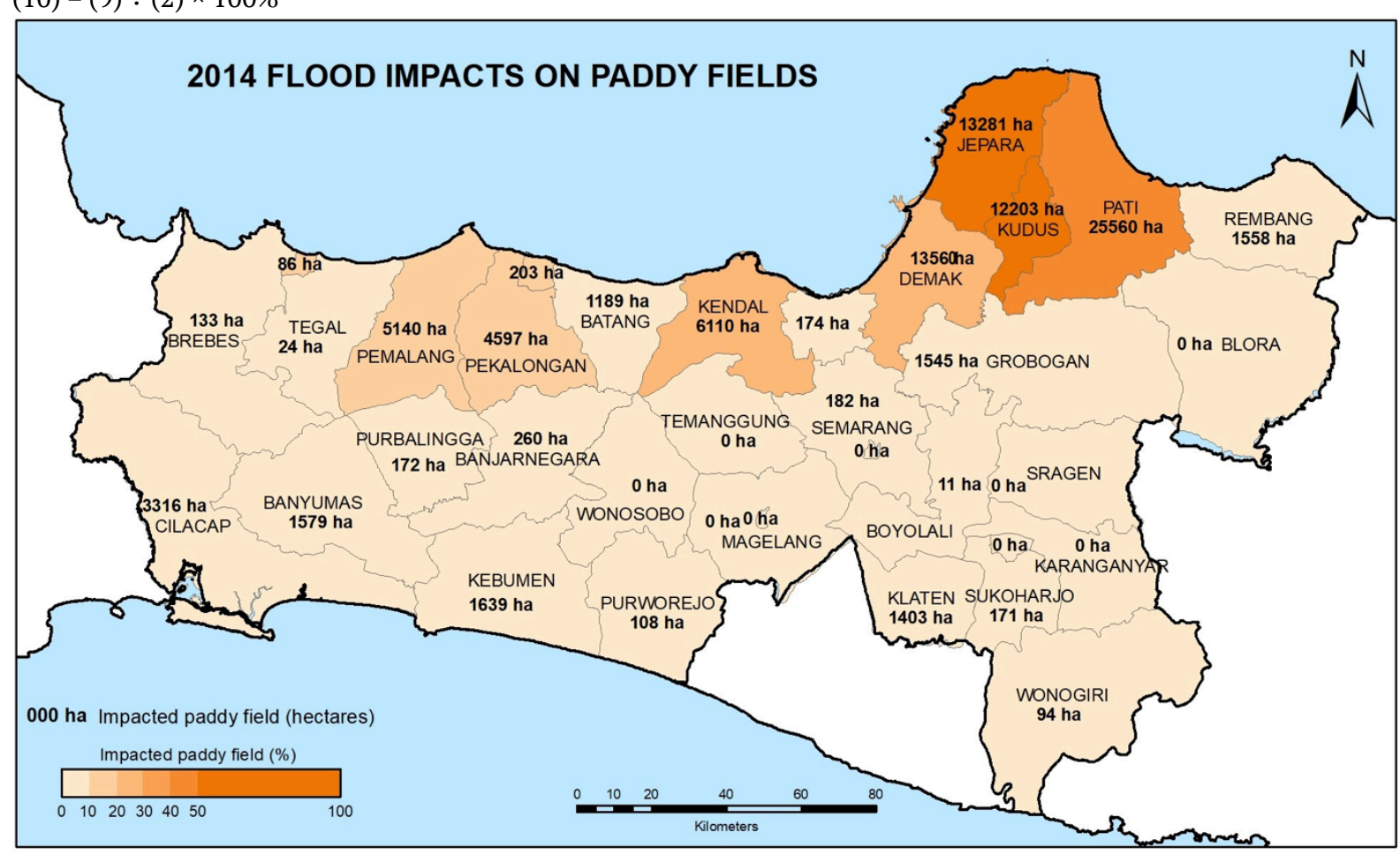

Figure 2. Spatial distribution of affected paddy fields in 35 regencies/cities due to flood in 2014

(Data sources: Office of Agriculture and Plantation, 2016; Ministry of Agriculture, Republic of Indonesia, 2018a)

Table 2 presents drought impacts on the paddy fields in Central Java. The most extreme drought happened in 2015. The total impacted area was 82,324 hectares, and the potential rice production loss was 496,002 tons. This value was about $4.39 \%$ of the total rice production in 2015. However, if we consider only the dry season (AprilSeptember 2015), the production loss was up to 11.44\%. The spatial distribution of the 2015 drought impacts displayed in Figure 3 shows that Blora, Cilacap, Grobogan, and Pemalang were the most significantly affected regencies. Meanwhile, according to a previous study, from 2010 to 2014, the drought-prone regencies in Central Java were Cilacap, Pemalang, Semarang, Demak, Grobogan, Sragen, Rembang, and Pati (Sumastuti \& Pradono, 2016). 
Table 2. Drought-affected paddy field areas in Central Java

\begin{tabular}{|c|c|c|c|c|c|c|c|c|c|}
\hline \multirow{3}{*}{ Year } & \multirow{3}{*}{$\begin{array}{c}\begin{array}{c}\text { Total } \\
\text { cultivated } \\
\text { area }\end{array} \\
\text { ha }\end{array}$} & \multirow{3}{*}{$\begin{array}{c}\begin{array}{c}\text { Land } \\
\text { productivity }\end{array} \\
100 \mathrm{~kg} / \mathrm{ha} \\
\end{array}$} & \multirow{3}{*}{$\begin{array}{c}\text { Actual rice } \\
\text { production }\end{array}$} & \multicolumn{6}{|c|}{ Drought impacts } \\
\hline & & & & \multicolumn{2}{|c|}{ Affected crop area } & \multicolumn{2}{|c|}{ Crop failure area } & \multicolumn{2}{|c|}{$\begin{array}{c}\text { Estimated } \\
\text { Production loss }\end{array}$} \\
\hline & & & & ha & $\%$ & ha & $\%$ & tons & $\%$ \\
\hline$(1)$ & (2) & (3) & & (5) & (6) & (7) & (8) & - & 10) \\
\hline 2014 & 04,6 & & & & & 3,45 & 0.19 & & 0.94 \\
\hline 2015 & $1,864,6$ & 60. & 2 & 6 & 3.43 & 18,280 & 0.98 & 496,002 & 4.39 \\
\hline 2016 & $1,953,593$ & 58.73 & $11,473,161$ & 15,016 & 0.77 & 3,032 & 0.16 & 105,996 & 0.92 \\
\hline 2017 & $2,010,465$ & 56.68 & $11,396,263$ & 2,918 & 0.15 & 187 & 0.01 & 17,599 & 0.15 \\
\hline 2018 & $1,954,476$ & 58.34 & $11,401,821$ & 43,928 & 2.25 & 9,997 & 0.51 & 314,598 & 2.76 \\
\hline
\end{tabular}

(1), (2), (3), (4) Data sources: Ministry of Agriculture, Republic of Indonesia (2019)

(5), (7) Data sources: Ministry of Agriculture, Republic of Indonesia (2018b, 2015)

(6) $=(5) \div(2) \times 100 \%$

$(8)=(7) \div(2) \times 100 \%$

$(9)=[(5)+(7)] \div(2) \times 100 \%$

$(10)=(9) \div(2) \times 100 \%$

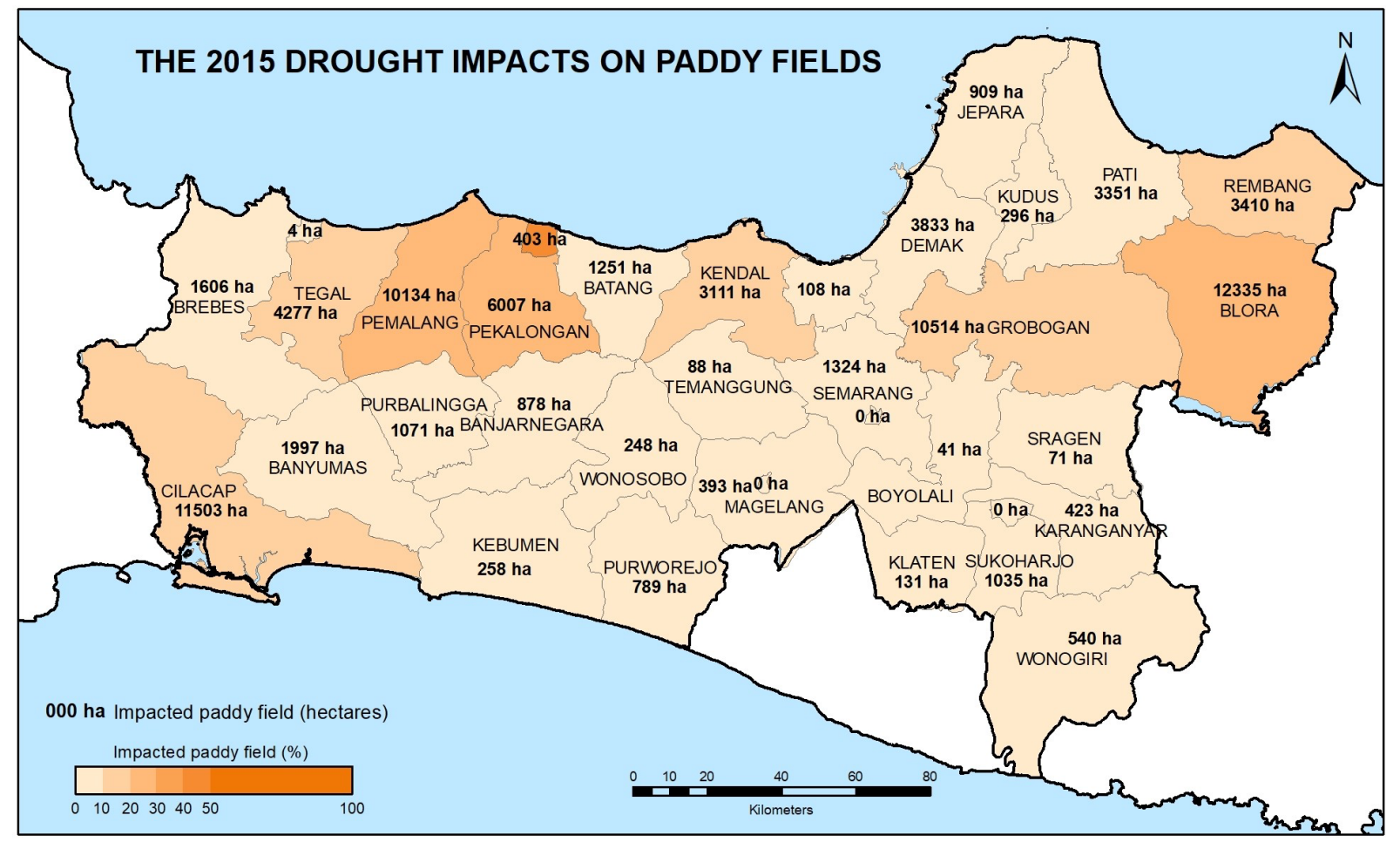

Figure 3. Spatial distribution of the impacted paddy fields in 35 regencies/cities caused by drought in 2015 (Data sources: Office of Agriculture and Plantation, 2016; Ministry of Agriculture, Republic of Indonesia, 2018a)

The relationship between drought and agriculture is particularly important, as $84 \%$ of the damage and losses caused by droughts relates to the agriculture sector (FAO, 2015). Lesk et al. (2016) found that globally, droughts and extreme heat significantly reduced national cereal production by $9 \%-10 \%$, whereas the analysis could not identify flood and extreme cold effects. Drought disasters in Indonesia mostly occur in Java and Madura since both islands have higher risk and vulnerability than other islands (Maarif, 2011).

Rainfall is a climate factor that is strongly correlated with flood and drought. Furthermore, Kang et al. (2009) claimed that crop yield is more sensitive to precipitation than temperature. 
Figure 4 depicts the annual rainfall deviation and flood- and drought-affected paddy field areas. The annual rainfall has a moderate linear correlation with flood or drought impact as shown in Figure 5. The results of Pearson's correlation analysis show that the correlation between annual rainfall and drought impact $(r=-0.865)$ is stronger than the correlation between rainfall and flood impact $(r=0.794)$. The correlation between annual rainfall and drought impact is statistically significant $(p=0.058)$, whether the correlation between rainfall and flood impact is inconclusive $(p=0.108)$ at a confidence level of $10 \%$. This finding corroborates with that of a previous study conducted in West Java (Estiningtyas et al., 2009), showing higher chances of drought than flood when rainfall shift occurs.

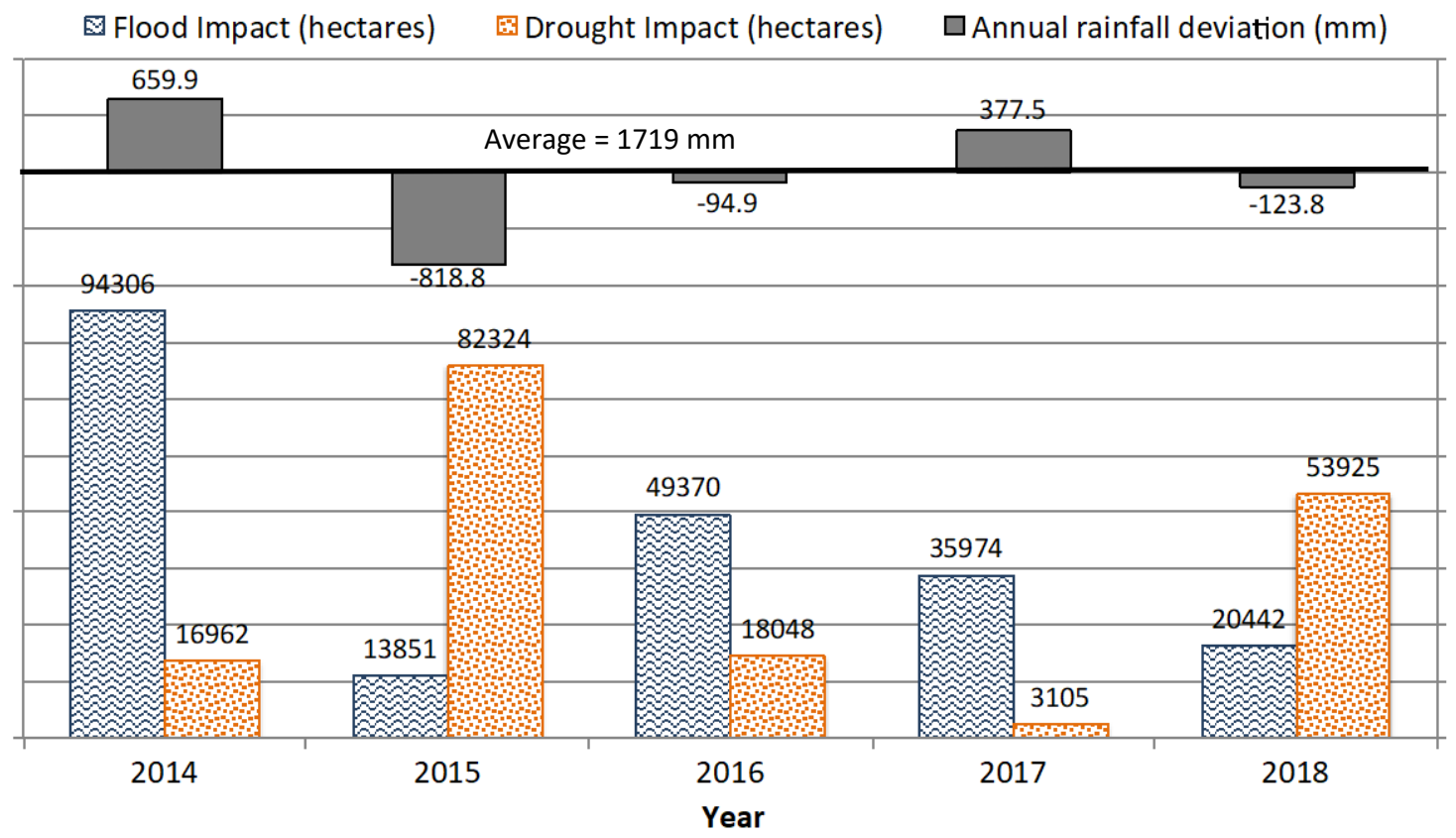

Figure 4. Disasters impact and annual rainfall deviation based on annual rainfall from 2014 to 2018

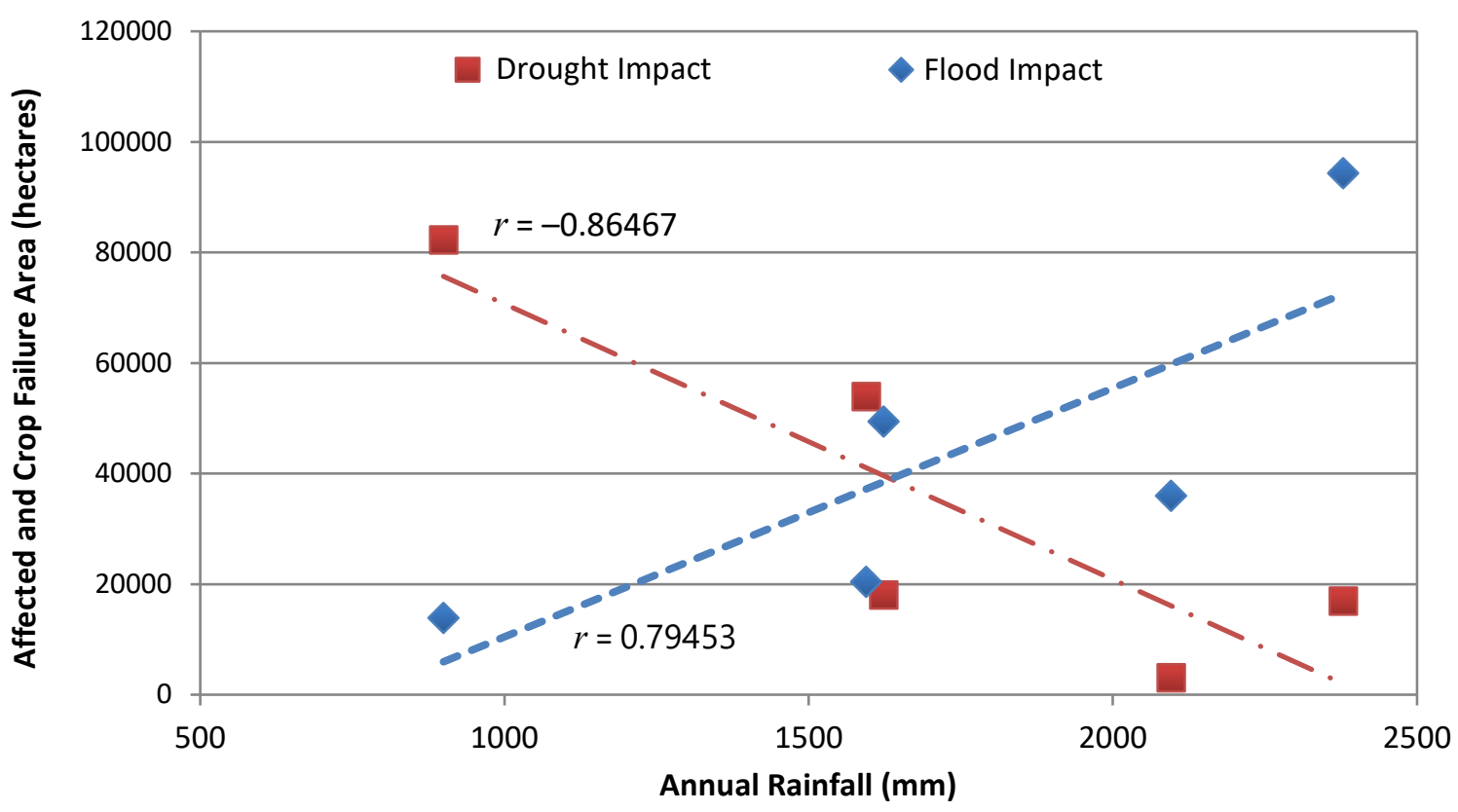

Figure 5. Pearson's correlation between annual rainfall and flood impact (blue), and annual rainfall and drought impact (red) 
Although the total rainfall in 2016 is less than the average annual rainfall from 2014 to 2018, the flood impact is greater than the drought impact because of an anomaly on rainfall temporal distribution. Typically, January-March and October-December are the wet seasons, while the dry season lasts from April to September. In 2016, however, rainfall was recorded the entire year, and there was almost no dry month. Thus, flood disasters attacked every month. In the early period of the year 2016, some parts of Central Java were still struck by drought, a continuation from the severe drought of 2015, but practically, no drought was recorded after that.

\subsection{Mitigation Strategies and Future Challenges}

Government institutions have taken several actions as flood and drought mitigation strategies. The Office of Public Works and Spatial Planning of Central Java established a 1,000 small dams and reservoirs construction program in 2015 and provided temporary pump irrigation during the dry season. The Ministry of Agriculture took the initiative to introduce, advocate, and disseminate rice farm insurance through the Agriculture Insurance Working Group. The main determination is to protect the farmers when a flood, drought, or crop pest attack occurs and cause crop failure. In the future, more extreme events are projected to occur more frequently with the strongest intensity. Droughts are likely to become more frequent in some regions (Lesk et al., 2016). Valizadeh et al. (2014) predicted that the production of future crops will be affected by climate change and will decrease. Kang et al. (2009) also maintained that with the temperature increase and precipitation fluctuations, water availability and crop production are likely to decrease in the future.

The strategies mentioned above, unfortunately, have not sufficiently reduced the impact of the current disasters, especially drought, even less the future disasters. Areas impacted by drought in a year between 2014 and 2018 (in the current study) were on average 50\% higher than those affected in a year between 2010 and 2014 (Sumastuti \& Pradono, 2016). If water availability is reduced in the future, growing crops on soils with high water-holding capacity will be better to reduce the impact of drought while maintaining crop yield (Kang et al., 2009). Enenkel et al. (2015) proposed to minimize drought impacts by integrating satellite-derived soil moisture measurements that link atmospheric processes to anomalies on the land surface to improved longrange weather predictions and mobile applications.

By learning and understanding the nature and distribution of floods and droughts from historical records, treatments can be implemented to reduce the risks. However, another concern is the availability and integration of disaster data. Data on disaster damage and losses in the agriculture sector are not systematically collected or reported. Consequently, natural disaster information is often incomplete or imprecise.

\section{CONCLUSION}

The present work is an initial study summarizing the effects of floods and droughts on paddy fields in Central Java in the last five years. The results highlight the vulnerability of the study area to flood and drought. Some measures against floods and drought have been adopted, yet the outcomes are still not satisfying. In the future, comprehensive assessments of climate change scenarios, interaction mechanisms between natural disasters and climate change, as well as strategy adaptations to reduce the vulnerabilities to food insecurity in Central Java should be conducted to further study the impacts of flood and drought on food security in Central Java.

\section{DISCLAIMER}

The authors declare no conflict of interest.

\section{ACKNOWLEDGMENTS}

This work was financially supported by the Department of Civil and Environmental Engineering, Faculty of Engineering, Universitas Gadjah Mada. The authors wish to thank the anonymous reviewers for their comments and suggestions. 


\section{REFERENCES}

Devereux, S., 2007. The impact of droughts and floods on food security and policy options to alleviate negative effects. Agricultural Economics, 37(S1), pp.47-58.

Enenkel, M., See, L., Bonifacio, R., Boken, V., Chaney, N., Vinck, P., You, L., Dutra, E. and Anderson, M., 2015. Drought and food security Improving decision-support via new technologies and innovative collaboration. Global Food Security, [online] 4, pp.51-55. Available at: <http://dx.doi.org/10.1016/j.gfs.2014.08.005>.

Estiningtyas, W., Boer, R. and Buono, A., 2009. Analisis Hubungan Hujan Dengan Kejadian Banjir dan Kekeringan pada Wilayah dengan Sistim Usaha Tani Berbasis Padi di Provinsi Jawa Barat. Jurnal Agromet, 23(39870423), pp.946-952.

FAO, 2015. The Impact of Natural Hazards and Disasters on Agriculture and Food Security and Nutrition: A Call for Action to Build Resilient Livelihoods. Rome: Food and Agriculture Organization of the United Nations.

Food and Agriculture Organization (FAO), 1996. Rome Declaration on World Food Security and World Food Summit Plan of Action. World Food Summit 13-17 November 1996. Rome.

Guo, J., Mao, K., Zhao, Y., Lu, Z. and Xiaoping, L., 2019. Impact of climate on food security in mainland China: A new perspective based on characteristics of major agricultural natural disasters and grain loss. Sustainability (Switzerland), 11(3), pp.1-25.

Indonesia Disaster Data Information, 2019. Disaster Spatial Distribution by Provinces. [online] The National Disaster Management Agency (BNPB). Available at: <http://dibi.bnpb.go.id/> [Accessed 19 Sep. 2019].

Kang, Y., Khan, S. and Ma, X., 2009. Climate change impacts on crop yield, crop water productivity and food security - A review. Progress in Natural Science, [online] 19(12), pp.1665-1674. Available at: <http://dx.doi.org/10.1016/j.pnsc.2009.08.001>.
Lesk, C., Rowhani, P. and Ramankutty, N., 2016. Influence of extreme weather disasters on global crop production. Nature, [online] 529(7584), pp.84-87. Available at: <http://dx.doi.org/10.1038/nature16467>.

Lolemtum, J.T., Mugavalai, E.M. and Obiri, J.A., 2017. Impact of drought on food security in West Pokot County, Kenya. International Journal of Scientific and Research Publication, 7(6), pp.742750.

Maarif, S., 2011. Meningkatkan kapasitas masyarakat dalam mengatasi risiko bencana kekeringan (Enhancing people's capacity for drought risk mitigation). Jurnal Sains dan Teknologi Indonesia, 13(2), pp.65-73.

Marfai, M.A., King, L., Singh, L.P., Mardiatno, D., Sartohadi, J., Hadmoko, D.S. and Dewi, A., 2008. Natural hazards in Central Java Province, Indonesia: An overview. Environmental Geology, 56(2), pp.335-351.

Ministry of Agriculture Republic Indonesia, 2015. Statistics of Climate, Crop Pest and Climate Change Impact 2012 - 2015. Center for Agricultural Data and Information System, Secretariate General Ministry of Agriculture.

Ministry of Agriculture Republic Indonesia, 2018a. Statistics of Agricultural Land 2013-2017. Center for Agricultural Data and Information System, Secretariate General - Ministry of Agriculture.

Ministry of Agriculture Republic Indonesia, 2018b. Statistics of Climate, Crop Pest and Climate Change Impact 2016-2018. Center for Agricultural Data and Information System, Secretariate General - Ministry of Agriculture.

Ministry of Agriculture Republic Indonesia, 2019. Data of Food Crops Sub-sector 2014-2018.

Office of Agriculture and Plantation, 2016. Statistical Data of Crops in Central Java 2015. Office of Agriculture and Plantation Central Java.

Pacetti, T., Caporali, E. and Rulli, M.C., 2017. Floods and food security: A method to estimate 
the effect of inundation on crops availability. Advances in Water Resources, [online] 110, pp.494-504. Available at: <https://doi.org/10.1016/j.advwatres.2017.06.019 $>$.

Sumastuti, E. and Pradono, N.S., 2016. Dampak perubahan iklim pada tanaman padi di Jawa Tengah (The Impact of Climate Change on Rice
Crops in Central Java). Journal of Economic Education, 5(1), pp.31-38.

Valizadeh, J., Ziaei, S.M. and Mazloumzadeh, S.M., 2014. Assessing climate change impacts on wheat production (a case study). Journal of the Saudi Society of Agricultural Sciences, [online] 13(2), pp.107-115. Available at: <http://dx.doi.org/10.1016/j.jssas.2013.02.002>. 
[This page is intentionally left blank] 